\title{
Virtual experimental platforms in chemistry laboratory education and its impact on experimental self-efficacy
}

\author{
Vysakh Kani Kolil*, Sharanya Muthupalani and Krishnashree Achuthan
}

\author{
*Correspondence: \\ vysakhkk@am.amrita.edu \\ Center for Cybersecurity Systems \\ and Networks, Amrita Vishwa \\ Vidyapeetham, Amritapuri Campus, \\ Kollam Kerala-690525, India
}

\begin{abstract}
Self-efficacy is an important determinant in successfully attempting a task. In the area of education, self-efficacy plays a crucial role in causing behavioral changes, resulting in enhanced performance over the course of learning. In chemistry education, students often develop anxiety towards performing experiments due to the perceived negative outcomes resulting from lack of understanding and improper experimentation. This anxiety negatively impacts the self-efficacy of students in performing laboratory experiments. We define student-held beliefs about their experimental skills as 'experimental self-efficacy' (ESE), and examine the four prominent factors that impact ESE in chemical laboratories. Through the development of an instrument, this work characterizes ESE and the impact of pre-laboratory interventions such as exposure to virtual laboratories (VL) on ESE and conceptual knowledge of students. Furthermore, analysis using statistical techniques such as $t$-tests and dissimilarity matrices reveal the positive impact of VL in enhancing students' ESE.
\end{abstract}

Keywords: Self-efficacy, Anxiety, Chemistry, Virtual laboratory, Physical laboratory, Conceptual learning

\section{Introduction}

Like theory and concepts, experimentation in laboratories is fundamental to Science, Technology, Engineering, and Mathematics (STEM) education. Several researchers report that practical experimentation plays an essential role in science and engineering education (Heradio et al. 2016; Waldrop 2013; De Jong et al. 2013; Winkelmann et al. 2014; Lasica et al. 2016). Laboratory activities are a mode of instruction to enhance undergraduate (UG) students' achievement, conceptual understanding, enhance their positive attitudes and improve cognitive growth (Hofstein et al. 2001; Lazarowitz and Tamir 1994).

According to the literature, an important determinant of academic outcomes is selfefficacy (Chemers et al. 2001; Gore Jr 2006; Putwain et al. 2013; Richardson et al. 2012; Robbins et al. 2004; Eakman et al. 2019).Our study focuses on the effect of self-efficacy on the laboratory performance of UG students in India. Self-efficacy, as proposed by A.

(c) The Author(s). 2020 Open Access This article is licensed under a Creative Commons Attribution 4.0 International License, which permits use, sharing, adaptation, distribution and reproduction in any medium or format, as long as you give appropriate credit to the original author(s) and the source, provide a link to the Creative Commons licence, and indicate if changes were made. The images or other third party material in this article are included in the article's Creative Commons licence, unless indicated otherwise in a credit line to the material. If material is not included in the article's Creative Commons licence and your intended use is not permitted by statutory regulation or exceeds the permitted use, you will need to obtain permission directly from the copyright holder. To view a copy of this licence, visit http://creativecommons.org/licenses/by/4.0/. 
Bandura (1986) is defined as a person's judgment about his or her ability to organize and execute courses of action to produce the desired outcome.

Anxiety is an affective factor that can alter self-efficacy levels in STEM undergraduates in a way that affects their productivity and output significantly (Cobo-Rendón et al. 2020). Prior research reports that UG students face a general trend of increase in anxiety (Cooke et al. 2006; Stallman 2010). During university education, emotions play a key role in academic success, with findings suggesting that positive affect increases personal resources, creativity and problem-solving capacity (Fredrickson 2013), as well as selfefficacy (Oriol-Granado et al. 2017), and enhances academic performance (Ben-Eliyahu and Linnenbrink-Garcia 2013). A negative relationship has been found between selfefficacy and anxiety (Nie et al. 2011; Kurbanoglu and Akim 2010), and both psychological and affective well-being and self-efficacy are associated with academic performance (Bücker et al. 2018). UG students' affective wellbeing is unarguably significant to their experimental self-efficacy too (Tamannaeifar and Motaghedifard 2014; Yu and Luo 2018).

Within the realm of experimental sciences, students pursuing higher education experience anxiety due to a variety of reasons such as use of sophisticated equipment, complex procedures etc. (Kamaruddin et al. 2015). One of the areas wherein students experience high anxiety is chemistry laboratory education. Working with hazardous chemicals, using laboratory equipment, carrying out arduous chemical procedures, lack of adequate time, working as a team and the need to collect accurate data have been identified as the five collective facets of chemistry anxiety (Bowen 1999; Kamaruddin et al. 2019). In fact, the fear of chemicals is one of the two defining contexts of what is now commonly known as 'chemophobia' (Breslow 1993). It has been further observed that student perception of chemistry is contrary to its true nature (Huey 2013). Chemistry has a reputation for being complex and highly theoretical. Such fear turns into disappointment towards the subject (Jegede 2007; Eddy 2000). Over time, as anxiety levels are left unchecked, student interest in the subject deteriorates.

The council of graduate schools revealed that in chemistry, undergraduate enrolment over the past decade was slightly down, with an average annual decrease of more than 1\% (Widener 2018). Students find chemistry education challenging at tertiary level of study (Aikenhead 2003; Dalgety and Coll 2006; Treagust et al. 2000) resulting in declining enrolments and poor placements of employable graduates in industries (Osborne and Collins 2000; Weng et al. 2010). The worldwide decline in the enrollment of students in chemistry courses can be restored by reducing fear of the subject, particularly anxiety related to performing experiments (Kurbanoglu and Akim 2010; Tan and Arshad 2011; Yusuf 2014). Students need to be taught that chemistry is an autonomous science with both an intrinsic logic and methodology in order to reverse this situation and inspire new enthusiasm among chemistry practitioners (Pagliaro 2010; Stone 2005).

To that end, educators have been employing, to various degree of success, Internet and Communication Technologies (ICT) innovations in teaching. With the development of ICT, learning has become much easier and broadened beyond classroom walls. There are several online tools such as interactive multimedia web platforms, game-based learning and video lectures available for students which enable them to accrue and handle greater amounts of information and reduce their cognitive load (Achuthan et al. 2015; Ainsworth 2008; Vlachopoulos and Makri 2017). 
Our ICT intervention, Virtual laboratories (VL), is a platform containing simulated and remotely triggered laboratory experiments that allows students to learn scientific concepts governing the experiment easily through visualization and practice (Jones 2018). Several studies have highlighted the impact of virtual environments on students' selfefficacy (Wilde and Hsu 2019; Wang and Zhu 2019). VL was found to be more effective for improving difficult concepts and scientific inquiry self-efficacy (Husnaini and Chen 2019). Ghergulescu et al. (2019) developed an interactive VL that offers personalized features for students. The authors evaluated students' VL performance using self-directed learning (SDL) and self-efficacy (SE). Knowledge improvement was observed in students with low and high SDL and SE levels who utilised the interactive personalized VL. VL in conjunction with physical lab, significantly improved the self-efficacy of students for microbiology experiments (Makransky et al. 2016b). Improvements in students' learning gains, student engagement, self-efficacy, motivation, and achievement were observed after performing experiments in virtual labs (Goudsouzian et al. 2018; Reece and Butler 2017; Su and Cheng 2019; Dyrberg et al. 2017). VL also helped teachers to improve their understanding and confidence related to teaching science (Bautista and Boone 2015). Laboratory experiments cannot be divorced from the curriculum, leading to our research on self-efficacy in experimental environment. In addition, self-efficacy theory supports our focus on self-efficacy in experimental environments. We define "experimental selfefficacy" (ESE) as the belief in one's ability to successfully execute action and observation in a controlled way within an experimental environment to achieve its outcomes. This requires understanding and executing the experimental procedures meticulously in order to realize the experimental outcomes.

In this work, we only focus on issues affecting ESE in chemistry laboratory experimentation. Intuitively, student ESE should be high in order for them to perform experiments successfully. Measuring ESE is an important stepping stone towards taking preventive measures against chemistry anxiety. Although few studies have reported chemistry self-efficacy amongst students with their chemistry achievements, academic performance, attitude toward chemistry and learning experiences (Kurbanoglu and Akim 2010; Ramnarain and Ramaila 2018; Dalgety and Coll 2006; Villafañe et al. 2016; UzuntiryakiKondakci and Senay 2015; Uzuntiryaki-Kondakci and Capa-Aydin 2013; Winkelmann et al. 2014; Ferrell and Barbera 2015; Cook 2013; Richard et al. 2002), we have not come across studies that have characterized ESE. Adyin and Uzuntiryaki (2009) developed 6 item self-efficacy scale (SCL) for chemistry high school students as part of their high school chemistry self-efficacy scale (HCSS) and in (Uzuntiryaki and Aydın YÇ 2009) developed chemistry self-efficacy scale for college students (CCSS) but the instrument did not involve the dimensions of chemistry laboratory work. Identifying key causes for poor ESE in chemistry laboratory, this work helps assess ESE and delves into how it could be impacted.

In this research, our contribution is multifold. Firstly, we have investigated the factors contributing to low ESE in conventional chemistry laboratories. Secondly, we have built a virtual laboratory (VL) learning platform for chemistry experiments to assess its impact on enhancing the ESE of students. Thirdly, we have created an instrument to measure this experimental self-efficacy. Fourthly, we have compared the effect of physical and virtual laboratory on the experimental self-efficacy of students. 


\section{Theoretical framework}

Bandura's theory of self-efficacy has proven to be an immensely useful framework to scaffold the development of ESE in our work (Bandura 1977; Bandura and Walters 1977; Bandura 1986). The theory classifies behavior as a product of (1) the perceptions people hold about their own abilities, and (2) the consequences they expect to follow from their performances. Those who believe strongly in their abilities typically step up their efforts and persist in situations that appear threatening. In contrast, individuals inhibited by selfdoubt will diminish their efforts, if not give up entirely, thereby settling for compromised or sub-par outcomes (Bandura 1989). In academic achievement of students, self-efficacy plays an important role along with hope and engagement (Tomás et al. 2020). Reports suggest that students with high self-efficacy have showed higher level of participation in classrooms, greater efforts to study and better performance in exams (Galyon et al. 2012; AlDahdouh 2018) In comparison, low levels of self-efficacy are correlated with increased perception of difficulty of tasks and impaired ability in problem solving and performance (Bandura 1997; Feldman and Kubota 2015; Honicke and Broadbent 2016; Kumar and Daniel 2016) In chemistry pedagogy, there has been a recent shift in focus from teachers and students teaching and learning skills to student-held beliefs about their own academic competencies in the search for optimal results. Exploring these beliefs of self-efficacy as the tool to overcome existing issues faced by students and even their impact in the use of virtual technology in learning is the focus of ongoing research in the field. Nonetheless, self-efficacy is contextually bound (Judge et al. 2007). Self-efficacy should be studied as individuals anticipate and actually interact with the environment (Bandura 1981). However, recent research has not delved into how self-efficacy is impacted in specific environments. In our paper, we zero in the context of laboratories to test the ideas of the self-efficacy theory; terming student-held beliefs about their experimental skills as experimental self-efficacy. It is evident that self-efficacy is highly relevant to the learning success of the student; thus, it is necessary to investigate how to strengthen such academic self-efficacy beliefs to optimise performance in experimental environments. Reports suggests that students with high self-efficacy have showed higher level of participation in classrooms, efforts while studying and performance in exams (AlDahdouh 2018; Galyon et al. 2012). In our study, we are interested in assessing impact of virtual laboratory on students' beliefs about their ability to complete physical laboratory experimentation. Experimental work may require repeating experiments multiple times to determine noise and accuracy. If a student is unable to perform an experiment successfully in the laboratory, the primary reasons are either lack of understanding, lack of confidence or anxiety. All of these are indicators of low ESE. Hence successful completion of physical laboratory experiments that often requires performing experiments multiple times is a good way to gauge student's confidence and ease at doing experiments. Thus, we compare students' experimental self-efficacy in both physical laboratories and VL assisted physical laboratories.

\section{Methods}

\section{Participants}

The participants in this study were 1225 undergraduate (UG) students, selected randomly from 25 institutes of higher learning where general chemistry and corresponding 
laboratory classes are part of their degree program. Of the participants, $735(60 \%)$ were female, and 490 (40\%) were male and their ages ranged between 17 to 21 years.

The study had four phases. Phase I involved the identification of factors contributing to low experimental self-efficacy in physical laboratory and shortlisting of experiments that manifest these factors as issues in students. Phase II involved the design of a virtual laboratory $(\mathrm{VL})$ learning platform that was interactive and identically replicated the shortlisted practical experiments. Phase III involved the development of an experimental self-efficacy instrument, its validation followed by its implementation amongst the undergraduate students selected as part of this study. Phase IV involved the comparison of experimental self-efficacy (ESE) among students who performed experimentation in physical laboratory (PL) vs students who performed experimentation on virtual laboratory (VL) platform prior to PL experimentation.

\section{Phase I: Determination of factors influencing experimental self-efficacy}

Previous research shows that self-efficacy is positively related to the learning outcome. The learning outcome cannot be measured directly but may be assessed from learning performance. The effectiveness of e-learning platforms has traditionally been measured in terms of the learners' achievement (Xu et al. 2014). To study experimental self-efficacy (ESE) and students' attitude towards experiments in the practical laboratory, the first step was to identify the predominant causes of poor ESE in laboratories. This was done using: looking at the literature followed by direct feedback laboratory instructors, online surveys followed by in-person interview of students (Fig. 1A). Literature suggests science self-efficacy is negatively impacted by difficulty in conceptual understanding, procedural complexity of tasks, fear of chemicals and its spillage, and lack of sufficient resources to complete the tasks (Aydın and Uzuntiryaki 2009; Dalgety and Coll 2006; Lorsbach and Jinks 1999; Tymms 1997; Richard et al. 2002; Jones and Young 1995; Talton and Simpson 1986; Smist and Owen 1994; Lent et al. 1984; Williams 1994; Betz and Hackett 1983; Kamaruddin et al. 2015). We have then confirmed these factors through the post-laboratory surveys (see Supplementary information, S1) of UG students. In interviews conducted thereafter, undergraduate students confirmed that laboratory related anxiety is a dominant factor in impacting experimental self-efficacy. Some of the student feedback are "I love doing laboratory experiments but the unintended breakage of glass apparatus pulls me back from performing well" and "The major reason why I do not like

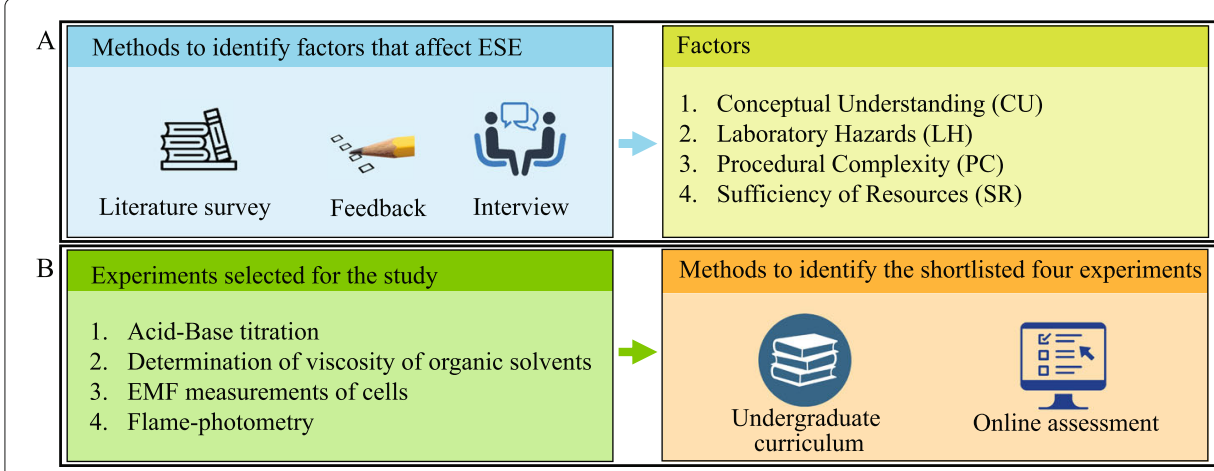

Fig. 1 Determination and analysis of the factors that impact experimental self-efficacy of the students 
physical experimentation is the improper understanding of the concept and the accidents happening by mistake."

An open-ended online survey for anxiety-causing factors (see Supplementary information, S1) was sent to all students that were part of this study. A total of 150 responses were received. Their responses on causes of anxiety were categorized into four broad categories. Out of all the participants, 91\% (137) identified conceptual understanding (CU) as one of the main factors that contributed to their anxiety in performing physical laboratory experiments whereas $79 \%$ (119) of participants identified procedural complexity (PC) as the main cause of anxiety. $81 \%$ (122) students named laboratory hazards (LH) as the biggest contributor to anxiety and 75\% (113) identified lack of sufficient resources (SR) as the factor that caused most anxiety in laboratory experimentation.

The factors that affect ESE in the laboratory environment were classified into two categories. Namely, cognitive and physical activities (Ramnarain and Ramaila 2018; Aydın and Uzuntiryaki 2009). Cognitive laboratory activities comprises of two factors; conceptual understanding and procedural complexity. CU refers to the grasp of the theory behind experiments and PC represents the difficulties faced by students in performing mathematical calculations and following the experimental steps. The physical laboratory activities comprises of two factors; laboratory hazards and lack of sufficient resources. LH represents instances such as accidental breakage of apparatus and spillage of chemicals whereas SR represents the unavailability of physical instruments, apparatus, and instructors to perform the experiments.

To systematically study these four factors, the next step was to shortlist a set of experiments that exemplified these anxiety-causing factors. The process of identification included a study of undergraduate chemistry laboratory curriculum. The UG chemistry curriculum for students aspiring to earn a Bachelor of Science (B. Sc.) degree in Science includes a set of experiments mandated by regulatory bodies such as UGC (University Grants Commission) (UGC 2019; 2015; DU 2011; BAMU 2020). Amongst these experiments, four experiments were shortlisted primarily from the feedback given by chemistry laboratory instructors based on their experience and interactions with students experiencing anxiety-induced difficulty with particular experiments. In addition, we ensured that experiments chosen for this study were common experiments every B. Sc. student will perform during the course of their study irrespective of the educational institution they went to so that results from this work had high practical value. The shortlisted experiments were: 1) Acid-Base titration, 2) Determination of viscosity of organic solvents, 3) EMF measurements of cells and 4) Flame-photometry (Fig. 1B).

The prevalence of anxiety caused by these factors i.e. CU, PC, LH and SR while performing the four shortlisted experiments was gauged through a survey conducted (see Supplementary information, S2) amongst 125 students. This was done also to further confirm that the selected experiments were in fact appropriate for the study. As such, students were allowed to select more than one factor that caused them anxiety while performing each experiment. Responses were collected from those who have performed these particular experiments in physical laboratory. Participants were not required to answer questions pertaining to all of the 4 chosen experiments. They were allowed to choose which experiments they wanted to answer questions about.

Results of this survey are tabulated in Table 1. The percentages in Table 1 represents the ratio of total number of students that selected a particular factor (i.e. LH, CU etc. 
Table 1 Factors impacting experimental self-efficacy in physical laboratories

\begin{tabular}{|c|c|c|c|c|c|}
\hline \multirow[t]{2}{*}{ \# No. } & \multirow[t]{2}{*}{ Experiment } & \multicolumn{4}{|c|}{ Factors } \\
\hline & & $\mathrm{CU}$ & $\mathrm{LH}$ & PC & SR \\
\hline 1 & Acid-base titration & $59 \%$ & $98 \%$ & $61 \%$ & $42 \%$ \\
\hline 2 & Determination of viscosity of solvents & $65 \%$ & $63 \%$ & $97 \%$ & $43 \%$ \\
\hline 3 & EMF measurements of cells & $94 \%$ & $56 \%$ & $72 \%$ & $48 \%$ \\
\hline 4 & Flame-photometry & $75 \%$ & $58 \%$ & $95 \%$ & $98 \%$ \\
\hline
\end{tabular}

represented in each column as causing anxiety) to the total number of students that gave feedback about the experiment. Out of 125 participants, 123 students responded to questions pertaining to acid-base titration and determination of viscosity of solvents. Of these participants, 121 (98\%) students selected LH as the main factor causing anxiety while performing acid-base titration. 119 (97\%) participants selected PC as the dominant anxiety-inducing factor in determination of viscosity of solvents. Likewise, out of 125 participants, 121 students answered questions pertaining to EMF measurements of cells and 124 answered questions related to flame-photometry. From the 121 participants who chose to answer questions about EMF measurements of cells experiment, 114 (94\%) selected $\mathrm{CU}$ as the dominant anxiety-inducing factor while performing EMF measurement of cells. Of 124 participants whose chose to answer questions on flame-photometry experiment, 122 (98\%) and 118 (95\%) participants selected SR and PC as the dominant factor in developing anxiety while performing flame-photometry in physical laboratory.

- Acid-Base titration: Acid-base titration is a commonly conducted laboratory experiment in all UG classes that deals with the determination of the concentration of acids or bases by neutralizing the acid or base (Atkins and De Paula 2017; Yadav 2010). In laboratory work, students should handle the glass apparatus like burette (a graduated glass tube with a tap at one end), pipette (a tube with bulb used to measure small amount of liquids), beaker (a cylindrical glass container), erlenmeyer flask (a glass container which features a flat bottom, a conical body, and a cylindrical neck) to neutralize the acid or base. Mishandling the glass apparatus will lead to the breakage of apparatus and $98 \%$ (Table 1) of the respondents felt this experiment impacted their self-efficacy from the perspective of laboratory hazards (LH).

- Determination of viscosity of solvents: Viscosity is the internal property of a fluid indicative of its resistance to flow as a function of several factors and measured by the Ostwald Viscometer (Yadav 2010). One needs to identify the time of flow of fluid, volume of the fluid, hydrostatic pressure, and the distance traveled by the fluid during time $t$ (Poiseuille's equation) to determine the viscosity of the solvents. The procedural complexity is relatively high in this experiment as confirmed by $97 \%$ (Table 1) of the respondents.

- Electromotive force (EMF) Measurements of cells: EMF measurement deals with the difference in potential of electrodes (anode and cathode) and the electric current (Atkins and De Paula 2017; Yadav 2010). To construct the electro-chemical cell and determine the EMF, students need to understand the concepts of oxidation potential and reduction potential at electrode-electrolyte surface, salt-bridge, Gibbs free energy, equilibrium constant and the spontaneity of the cell reaction. Students often 
lack conceptual understanding of the fundamental governing principles in this experiment as gathered from $94 \%$ (Table 1) of the respondents.

- Flame-photometry: Flame-photometry is an application of atomic absorption spectroscopy for determination of the concentration of alkali and alkaline earth metals (Trojanowicz 2000) using the flame-photometer. Students have to understand the concepts of thermal excitation of metals and emission of light in the visible region of the electromagnetic spectrum. The intensity of emitted light is used to determine the concentration of alkali and alkaline earth metals in ppm (parts per million) level (Scheibe-Lomakin equation) (Trojanowicz 2000). Students perform this experiment in groups due to insufficient resources to do this experiment individually leading to lower self-efficacy as indicated by $98 \%$ (Table 1) of the respondents. In addition, the procedural complexity was perceived to be high by $95 \%$ of respondents in this experiment.

\section{Phase II: Design of virtual laboratory experimentation}

Previous studies on enhancing visualization of physical phenomena through online platforms that allow learning from multi-modal resources (such as videos, simulations and animations) have shown significant improvements in conceptual understanding of hard to learn concepts amongst student improving their classroom performances (Beydoğan and Hayran 2015; Achuthan et al. 2018; Achuthan et al. 2017; Achuthan et al. 2015; Boboev et al. 2018). The development of Virtual lab platform included putting together multi modal content on several aspects of the experiment in the form of detailed theory notes, experimental procedures, self-evaluation questions, assignment questions and videos (Achuthan et al. 2011). Central to the platform was the virtual simulation of experiments done through online simulation and animation using FLASH and HTML5 software. The step-by-step development of the virtual experiments required significant involvement of chemistry laboratory instructors, story-boarding of individual steps followed by review of these experiments by experts (Fig. 2). All the contents (theoretical

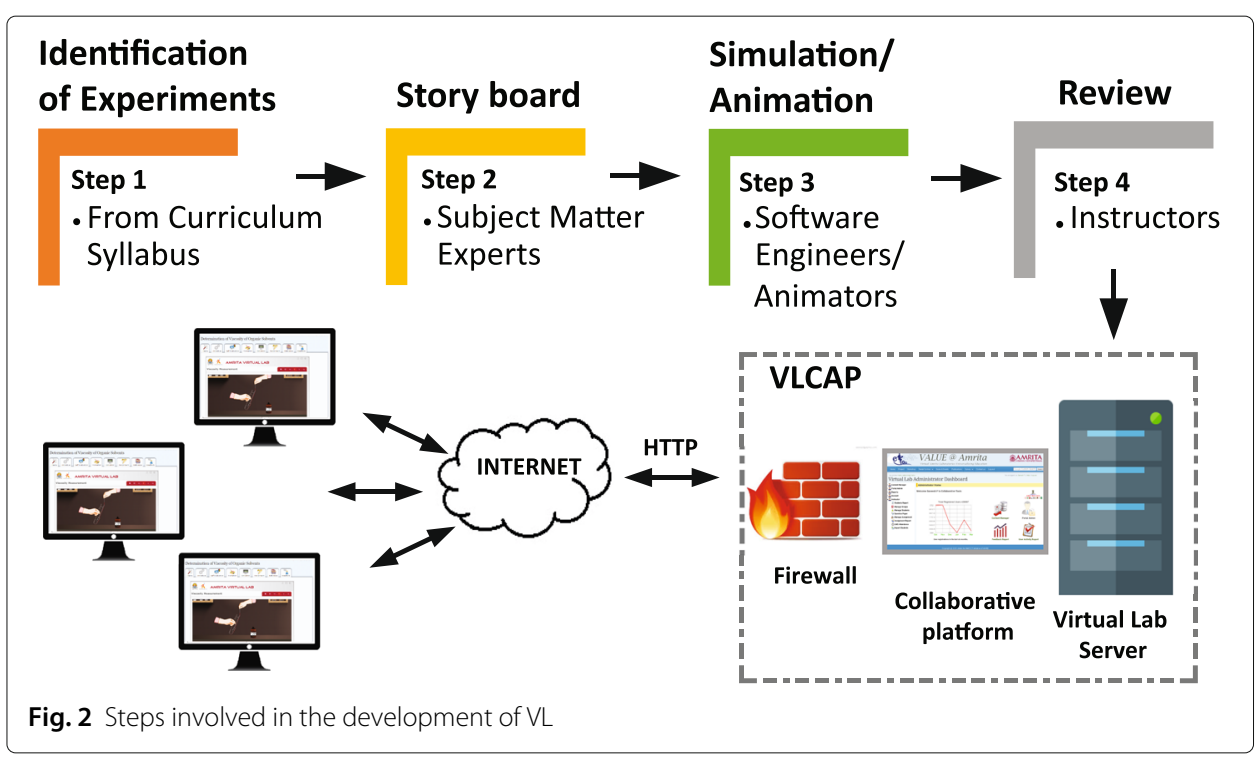


notes, simulation, videos etc.) related to an experiment is published in a collaborative platform called VLCAP (Virtual Labs Collaboration and Accessibility Platform) (Raman et al. 2011; Nedungadi et al. 2018; Raman et al. 2014) and which allows VL to be deployed in a hosted environment and securely accessed by learners in remote locations. The platform allowed 1) interactivity to enhance hands-on learning, 2) ability to do multiple experiments above and beyond what is done in physical laboratories (PL) 3) availability to perform the online experiments any number of times to help reinforce their skills.

To improve conceptual understanding of EMF measurement experiment, we created an interactive environment for performing the experiment virtually using graphical models of electrochemical cells, electrodes, electrolytes, salt-bridge and voltmeter. Furthermore, the platform allowed students to vary factors such as the ambient temperature that is impossible to do in a physical laboratory to study its impact on EMF. In addition, the VL platform presented in detail, the governing theory inclusive of chemical equations, symbolic representation of electro-chemical cell, standard hydrogen electrode, Nernst equation and table of contents to check spontaneity or feasibility of a reaction (Fig. 3a). For acid-base titration the VL platform incorporated scaled-down models of apparatus used in PL mimicking reality. In addition, the platform provided a detailed description

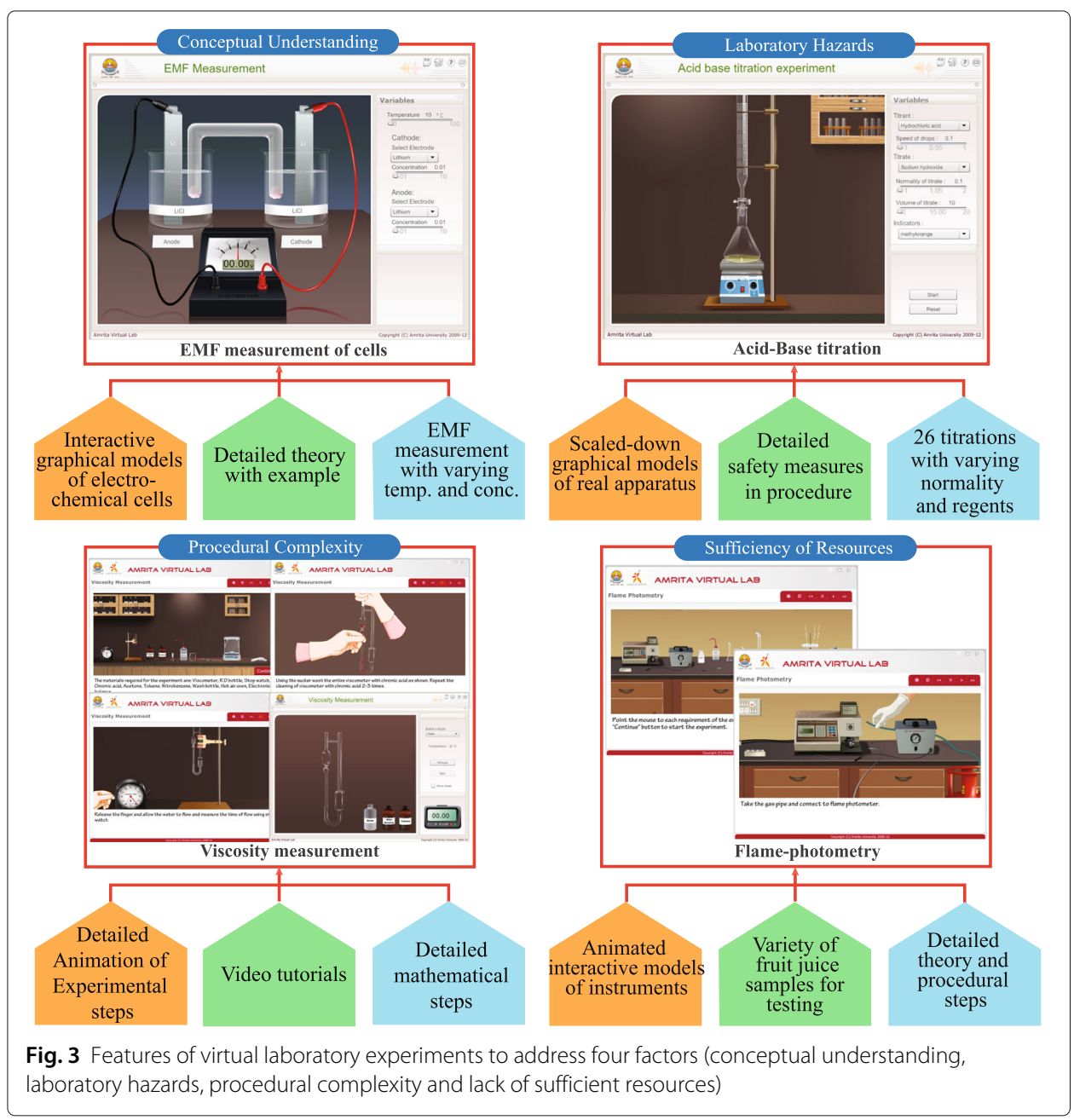


of safety measures that is to be followed for performing the experiment in PL. The platform also offered 26 titration experiments for students to experiment with using 5 acids, 4 bases and 3 indicators with varying degrees of normalities (Fig. 3b). For viscosity measurement, VL platform offered detailed animation and video tutorials of PL procedures that included washing of viscometer, determining the time of flow of solvents, and estimating the density of solvents to reduce procedural complexity. These helped students, with comprehending the governing equations for calculating viscosity and density of solvents (Fig. 3c). For flame-photometry VL provided a hands-on experience of operating the flame-photometer, pressure pump and cuvettes and so on emulating physical experimentation. Besides, a variety of fruit juice samples were provided for experimentation (Fig. 3d).

\section{Phase III: Development of experimental self-efficacy instrument}

Towards the objective of developing a reliable instrument to characterize experimental self-efficacy, twelve questions were developed (Table 2) based on the four factors (CU, LH, PC and SR) detailed in Table 1. Factor analysis was done using K1 rule (eigen value $>1$ ), scree plot analysis and parallel analysis, for the survey responses (Kaiser-Mayer-Olkin measure of sample adequacy is 0.80 ), and the 12 questions were divided into four factors, i.e. CU, LH, PC and SR (Table 3). Each factor had three associated questions and

Table 2 Experimental self-efficacy questionnaire

\begin{tabular}{|c|c|c|c|c|}
\hline Factors & Items & Questions & SD & $\alpha$ \\
\hline \multirow[t]{6}{*}{$\overline{C U}$} & 1 & I believe I have a sound grasp of the theory behind & 0.93 & 0.76 \\
\hline & & laboratory experiments before performing experiments. & & \\
\hline & 2 & Experimental concepts become clearer to me as & 0.87 & \\
\hline & & I perform the experiment. & & \\
\hline & 3 & I am confident that I understand the underlying & 0.88 & \\
\hline & & chemical phenomena in the experiment. & & \\
\hline \multirow[t]{5}{*}{$\mathrm{LH}$} & 4 & I can usually handle the glass apparatus in the laboratory & 0.86 & 0.82 \\
\hline & & on my own without any fear of breakage and injury. & & \\
\hline & 5 & $\begin{array}{l}\text { I am confident of working in the laboratory without } \\
\text { chemical spillage. }\end{array}$ & 0.86 & \\
\hline & 6 & I am always alert in the laboratory and have & 1.05 & \\
\hline & & minimal accidents. & & \\
\hline \multirow[t]{6}{*}{ PC } & 7 & After an experiment, I have no difficulty figuring out how & 0.86 & 0.89 \\
\hline & & my calculation procedures and errors affected my results. & & \\
\hline & 8 & When presented with laboratory results, I know how & 1.04 & \\
\hline & & to interpret them and draw relevant conclusions from them. & & \\
\hline & 9 & I do not struggle with processing information in background & 1.04 & \\
\hline & & articles and relating them to my own laboratory procedures and results. & & \\
\hline \multirow[t]{6}{*}{ SR } & 10 & I find it easy to complete the exercise in the laboratory & 1.03 & 0.72 \\
\hline & & even though there is limited personal participation in performing experiments. & & \\
\hline & 11 & It is easy for me to understand theory and concepts properly & 1.03 & \\
\hline & & in spite of limited availability of physical instruments. & & \\
\hline & 12 & I do not find it challenging to understand an experiment even & 0.93 & \\
\hline & & if there is only one try due to limited availability of chemicals. & & \\
\hline
\end{tabular}

$\mathrm{CU}=$ conceptual understanding, $\mathrm{LH}=$ laboratory hazards, $\mathrm{PC}=$ procedural complexity, $\mathrm{SR}=$ sufficiency of resources 
Table 3 Classification of questions based on factor analysis and reliability coefficients of the factors $\mathrm{CU}, \mathrm{LH}, \mathrm{PC}$ and SR in the ESE

\begin{tabular}{lllll}
\hline Item & Factor 1:PC & Factor 2: LH & Factor 3: CU & Factor 4: SR \\
\hline 1 & .189 & .008 & $\mathbf{. 7 3 5}$ & .047 \\
2 & -.035 & .078 & $\mathbf{. 8 5 1}$ & -.072 \\
3 & -.007 & .122 & $\mathbf{. 8 6 3}$ & -.070 \\
4 & .075 & $\mathbf{. 8 7 6}$ & -.005 & .031 \\
5 & .109 & $\mathbf{. 8 5 2}$ & .095 & -.136 \\
6 & .050 & $\mathbf{. 8 1 7}$ & .129 & -.163 \\
7 & $\mathbf{. 8 1 8}$ & .182 & .195 & -.323 \\
8 & $\mathbf{. 8 7 5}$ & .097 & .015 & -.279 \\
9 & $\mathbf{. 8 6 1}$ & -.004 & -.025 & -.251 \\
10 & -.278 & -.013 & .069 & $\mathbf{. 7 9 2}$ \\
11 & -.345 & -.195 & -.079 & $\mathbf{. 7 5 3}$ \\
12 & -.442 & -.151 & -.176 & $\mathbf{. 5 4 3}$ \\
Number of items & 3 & 3 & 3 & 3 \\
Item variance & 0.96 & 0.85 & 0.80 & 0.99 \\
Cronbach's Alpha $(\alpha)$ & 0.89 & 0.82 & 0.76 & 0.72 \\
\hline
\end{tabular}

Values in the bold (values above 0.5 ) are representing those that conform to that category

the content validity of the ESE scale was verified by experts from chemistry and educational psychology. Items in Table 2 i.e. \#1, \#2, and \#3 measures the self-efficacy related to students conceptual understanding and items \#4, \#5, and \#6 measures the self-efficacy related to students laboratory hazards. Similarly items \#7, \#8, and \#9 measures the selfefficacy of students in the experimental procedural complexity and items \#10, \#11, and \#12 measures the self-efficacy of students related to lack of sufficient resources in laboratory. Each item on the ESE questionnaire was rated on a 5-point Likert scale (1=strongly disagree to $5=$ strongly agree). The reliability coefficient $(\alpha)$ (DeVellis 2016) value for each factor was computed as follows: $\mathrm{CU}=0.76, \mathrm{LH}=0.82, \mathrm{PC}=0.89$, and $\mathrm{SR}=0.72$. The overall reliability coefficient of all twelve questions was found to be 0.86 (Table 2). The same set of questions described in Table 2 were used to assess both ESE-pre and ESE-post test.

\section{Phase IV - Characterization of experimental self-efficacy}

As a first step, prior to gauging the experimental self-efficacy of students, two tests i.e. the general self-efficacy (GSE) test and computer self-efficacy (CSE) test were administered to all students (Fig. 4). The reason to administer GSE was to screen any outliers in the group. The CSE test was done for two reasons: 1) laboratory experiments are often interfaced with computers for data acquisition, plotting and so on and 2) understanding CSE is a useful precursor to determine the student's attitude towards pre-lab interventions such as working with computer simulations. In the context of computer use, Compeau \& Higgins have defined CSE as "a judgment of one's capability to use a computer" (Compeau and Higgins 1995) and students with high levels of CSE are more likely to use e-learning platform (Hsia and Tseng 2008; Moghadam and Bairamzadeh 2009; Yuen and Ma 2008). GSE was measured by a 10 item scale questionnaire (Schwarzer and Jerusalem 1995) while CSE was measured by another 10 item scale questionnaire adapted from Compeau and Higgins study (Compeau and Higgins 1995). Each item on the GSE questionnaire was rated on a 4-point Likert scale $(1=$ not at all true to $4=$ exactly true) and CSE questionnaire was rated on a 10 point Likert scale $(1=$ not at all confident to $10=$ totally confident). 


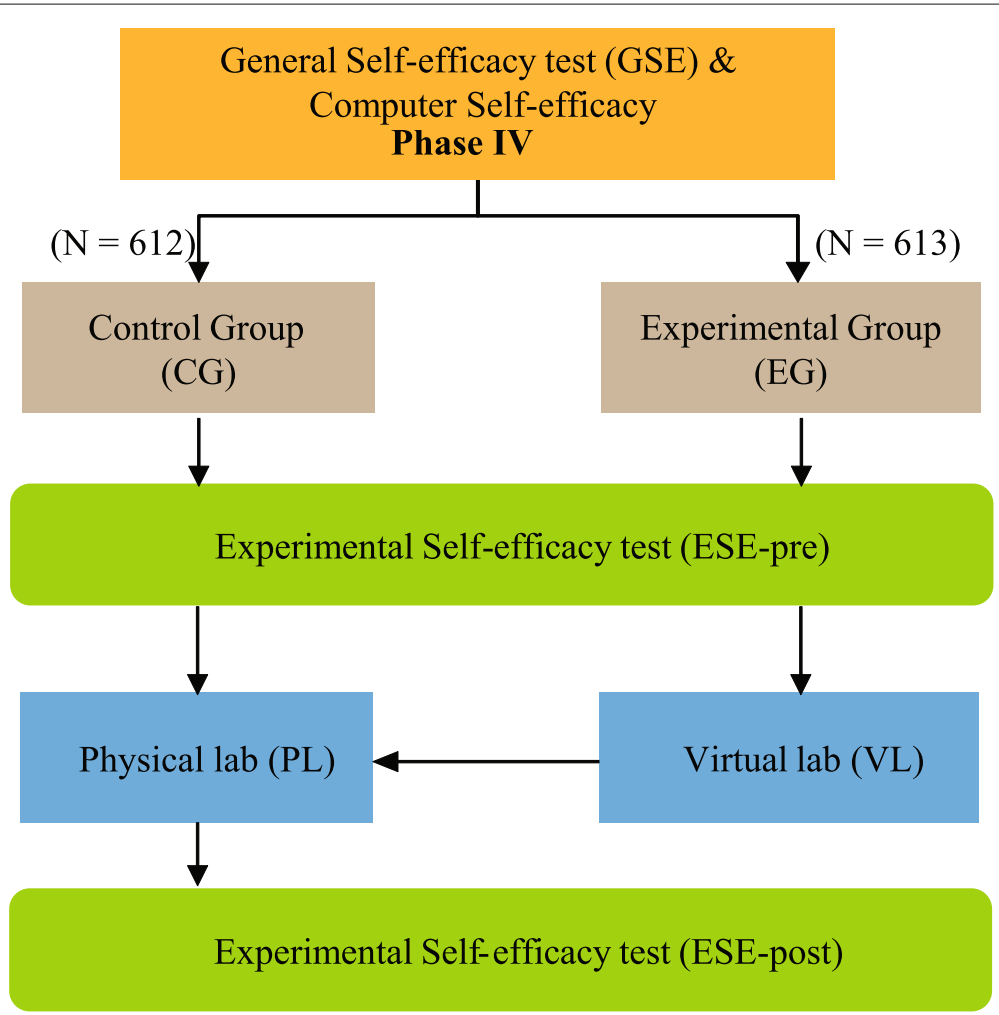

Fig. 4 Study design for the characterization of experimental self-efficacy of students

After assessing GSE and CSE, participants were divided into two groups, control group (CG, $N=612$ ) and experimental group (EG, $N=613$ ) and the self-efficacy of both groups were assessed using experimental self-efficacy questionnaire (ESE-pre) (Table 2) which was an online survey that took approximately 30 minutes to complete.

After ESE-pre, CG performed the experiments (acid-base titration, determination of viscosity of solvents, emf measurements of cells and flame-photometry) in the physical laboratory and it took approximately 2 hours per experiment. On the other hand, EG went through a one-hour practice session on the virtual simulated platforms prior to performing the same experiments in the physical laboratory. The emf measurements of cells and flame-photometry experiments were performed in groups of 3-5 students in physical laboratory owing to the limited number of physical instruments. The self-efficacy of both groups (CG and EG) were again assessed using the same 30 minute ESE questionnaire (ESE-post) (Table 2) after laboratory experimentation. Each of 12 items in the ESE instrument could carry between 1-5 points and a student could score a maximum 60 points. For the analysis, we classified scores in the following way: 1) between 12 and 23 points as low self-efficacy 2) between 24 and 35 points as below average self-efficacy 3 ) between 36 and 47 points as above average self-efficacy and 4) between 48 and 60 points as high self-efficacy (Fig. 4).

\section{Results and Discussion}

The analysis of general self-efficacy (GSE) and computer self-efficacy (CSE) of all the participants confirmed that the selected participants in this study scored above average in 
their general self-efficacy (GSE) and computer self-efficacy (CSE). The GSE scores of the participants were calculated based on a score range between 10-40; where the scores 10 and 40 represent the minimum and maximum scores that can be obtained in the test. In our study, scores above 30 were considered as above average GSE. Similarly, for CSE, the score range is between $10-100$ and the scores above 60 were considered as above average CSE.

\section{Experimental self-efficacy of students}

Experimental self-efficacy test (ESE-pre) was conducted on both groups (CG and EG) before they performed physical and virtual lab experiments as shown in Table 4. The groups were allocated 30 minutes to complete the questionnaire. The results of the experimental self-efficacy test of CG and EG are represented in Fig. 5. The results showed that in ESE-pre, most students in both groups have low (CG = 306 students, 50\% and EG = 331 students, $54 \%$ ) and below average (CG $=306$ students, 50\% and EG = 282 students, 46\%) experimental self-efficacy scores. None of the students in CG and EG demonstrated high experimental and above average self-efficacy scores before performing the experiments. The paired t-test analysis assuming unequal variance of CG and EG after ESE-pre showed no significant difference between groups $(\mathrm{t}(1223)=0.20, \mathrm{p}=0.84)$. The analysis data of CG were Mpre $=23.04, \sigma_{\text {pre }}=5.57$ and EG is Mpre $=22.82, \sigma_{\text {pre }}=5.31$ (Table 4). The low self-efficacy scores of most students suggested that they suffer from anxiety while performing experiments in laboratories (Kurbanoglu and Akim 2010; Kurbaşlar et al. 2015).

After performing the physical and virtual lab experiments, students' self-efficacy were re-analyzed for CG and EG using the same ESE questionnaire (named ESE-post) for a duration of 30 minutes. The results of the ESE-post test is described in the Fig. 5. From the figure, we observed a noticeable difference in the self-efficacy scores of the students in CG and EG. In the CG, the number of students with low self-efficacy scores decreased to zero from the initial 306 (50\%) whereas the number of students with high self-efficacy increased from zero to 196 students (31.97\%). However, the experimental group showed a significant increase in the number of students who had high self-efficacy (zero to 417, $68.03 \%)$ and a large decrease in the number of students with low self-efficacy (331, 54\% to zero). The paired t-test analysis assuming unequal variance of the ESE-post results of CG and EG also showed significant difference $(\mathrm{t}(1222)=-5.71, \mathrm{p}<0.05)\left(\mathrm{CG}: \mathrm{M}_{\text {post }}=38.76\right.$, $\sigma_{\text {post }}=12.84 ; \mathrm{EG}: \mathrm{M}_{\text {post }}=50.22, \sigma_{\text {post }}=6.08$ ) (Table 4). The increase in the self-efficacy scores of students using VL implied that VL can be a valuable tool to help students perform experiments prior to entering the physical laboratory in the following ways. 1) It deepened their familiarity with experiments, with VL mimicking reality of a physical lab as closely as possible. Students with anxiety may also have more variation in results every time they perform the experiment. However, repeating difficult experiments over and

Table 4 t-statistics of experimental self-efficacy and test groups

\begin{tabular}{lllllllll}
\hline Groups & ESE-pre & \multicolumn{7}{c}{ ESE-post } \\
\cline { 2 - 9 } & $M$ & $\sigma$ & $t$ & $p$ & $M$ & $\sigma$ & $t$ & $p$ \\
\hline CG & 23.04 & 5.57 & 0.20 & 0.84 & 38.76 & 12.84 & -5.71 & $0.00^{*}$ \\
EG & 22.82 & 5.31 & & & 50.22 & 6.08 & & \\
\hline *Significant at the $p<0.05$ level & & & & & &
\end{tabular}




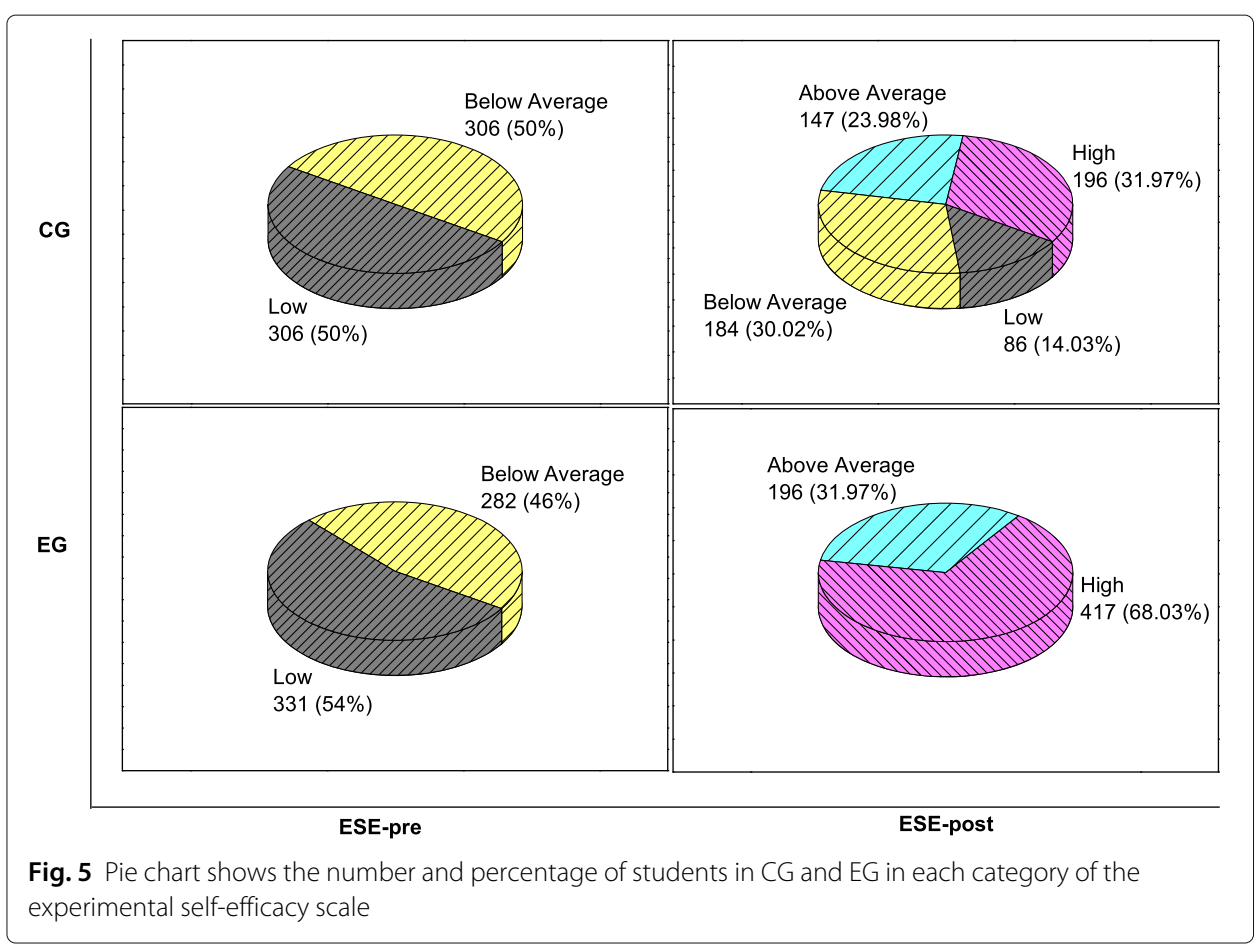

over again, which is impractical in a physical laboratory environment, increases the student's familiarity and therefore the chances of having consistent results and overcoming anxiety. VL further gives the students familiarity not only with the experimental procedures, but also expected results and a greater understanding of how to analyse results (Achuthan et al. 2018; Korakakis et al. 2009). 2) It removed the physical threat of spilled chemicals and broken apparatus, thereby providing a safe environment for students to make mistakes and learn from them prior to physically performing these experiments. De-linking laboratory work from physical hazards on the VL platform also freed students from stress induced anxiety, enabling them able to focus and imbibe experimental protocol more effectively with the VL interface. 3) Performing multiple experiments with the ability to vary more parameters on the VL platform reinforced the knowledge of procedural accuracy and helped students with conceptual understanding of the governing theories behind the experiments through visualization and repetition (Herga et al. 2016). Students thus have a higher chance of meeting the requirements of experimental assessment by using VL as having pre-lab intervention along with a reduced number of unfamiliar components in the laboratory before entering it, alleviates ESE. Hence the study of ESE in the context of chemistry laboratories, corroborates with the self-efficacy theory that suggests that self-efficacy is contextually bound and should be studied within a specific environment in order to realise how to strengthen students' ESE beliefs and improve their performance (Judge et al. 2007).

An independent sample t-test assuming unequal variance was used to compare selfefficacy score in ESE-pre and ESE-post of CG and EG. The results showed a significant difference in the average score for the CG (Mpre $=23.04$ and 38.76) and EG $\left(\mathrm{M}_{\text {post }}=22.82\right.$ and 50.22) of ESE-pre and ESE-post respectively (Table 4).

To investigate possible differences in experimental self-efficacy among the male and female students, we used independent sample t-test assuming unequal variance method. 
Table $\mathbf{5}$ t-test statistics of gender and experimental self-efficacy

\begin{tabular}{llllllllll}
\hline Groups & Gender (N) & \multicolumn{2}{l}{ ESE-pre } & \multicolumn{7}{c}{ ESE-post } \\
\cline { 3 - 10 } & & $M$ & $\sigma$ & $t$ & $p$ & $M$ & $\sigma$ & $t$ & $p$ \\
\hline CG & Male(245) & 22.90 & 5.51 & 0.14 & 0.89 & 40.4 & 14.44 & -0.70 & 0.49 \\
& Female(367) & 23.13 & 5.70 & & & 37.67 & 11.78 & & \\
\multirow{2}{*}{ EG } & Male(245) & 23.05 & 6.06 & -0.24 & 0.81 & 50.45 & 5.95 & -0.22 & 0.83 \\
& Female(368) & 22.67 & 4.86 & & & 50.07 & 6.25 & & \\
\hline
\end{tabular}

The results in Table 5 suggested no significant difference in ESE amongst male and female students (Wright and Holttum 2012; Kiran and Sungur 2012).

We examined the distribution of experimental self-efficacy scores of four factors, namely, conceptual understanding, laboratory hazards, procedural complexity and lack of sufficient resources using box plots (Fig. 6). The box plot in red shows the ESEpre score of students whereas the blue plot represents the ESE-post score of students in both control and experimental groups. These plots show the ranges from minimum to maximum, the average score (solid horizontal line) and the four interquartile ranges of both groups. In the case of CU, the CG shows $60 \%\left(\mathrm{M}_{\text {pre }}=5.94 ; M_{\text {post }}=9.48\right)$ improvement in ESE score between pre and post tests and EG shows $111 \%\left(\mathrm{M}_{\text {pre }}=5.90\right.$; $\left.\mathrm{M}_{\text {post }}=12.42\right)$ improvement in the ESE score. The result is supported by Trindade et al. (2002). Similarly, LH shows $66 \%\left(\mathrm{M}_{\text {pre }}=5.94 ; \mathrm{M}_{\text {post }}=9.84\right)$ improvement in CG and $135 \%\left(\mathrm{M}_{\text {pre }}=5.40 ; \mathrm{M}_{\text {post }}=12.68\right)$ improvement in EG respectively. PC shows $81 \%$ $\left(\mathrm{M}_{\text {pre }}=5.48 ; \mathrm{M}_{\text {post }}=9.92\right)$ improvement in $\mathrm{CG}$ and $117 \%\left(\mathrm{M}_{\text {pre }}=5.84 ; \mathrm{M}_{\text {post }}=12.68\right)$ improvement in EG. Finally, SR shows $68 \%\left(\mathrm{M}_{\text {pre }}=5.68 ; \mathrm{M}_{\text {post }}=9.52\right)$ improvement in CG and $119 \%\left(\mathrm{M}_{\text {pre }}=5.68 ; \mathrm{M}_{\text {post }}=12.44\right)$ improvement in EG. We used the dissimilarity matrix analysis and the re-scaled Euclidean distance to estimate the difference in

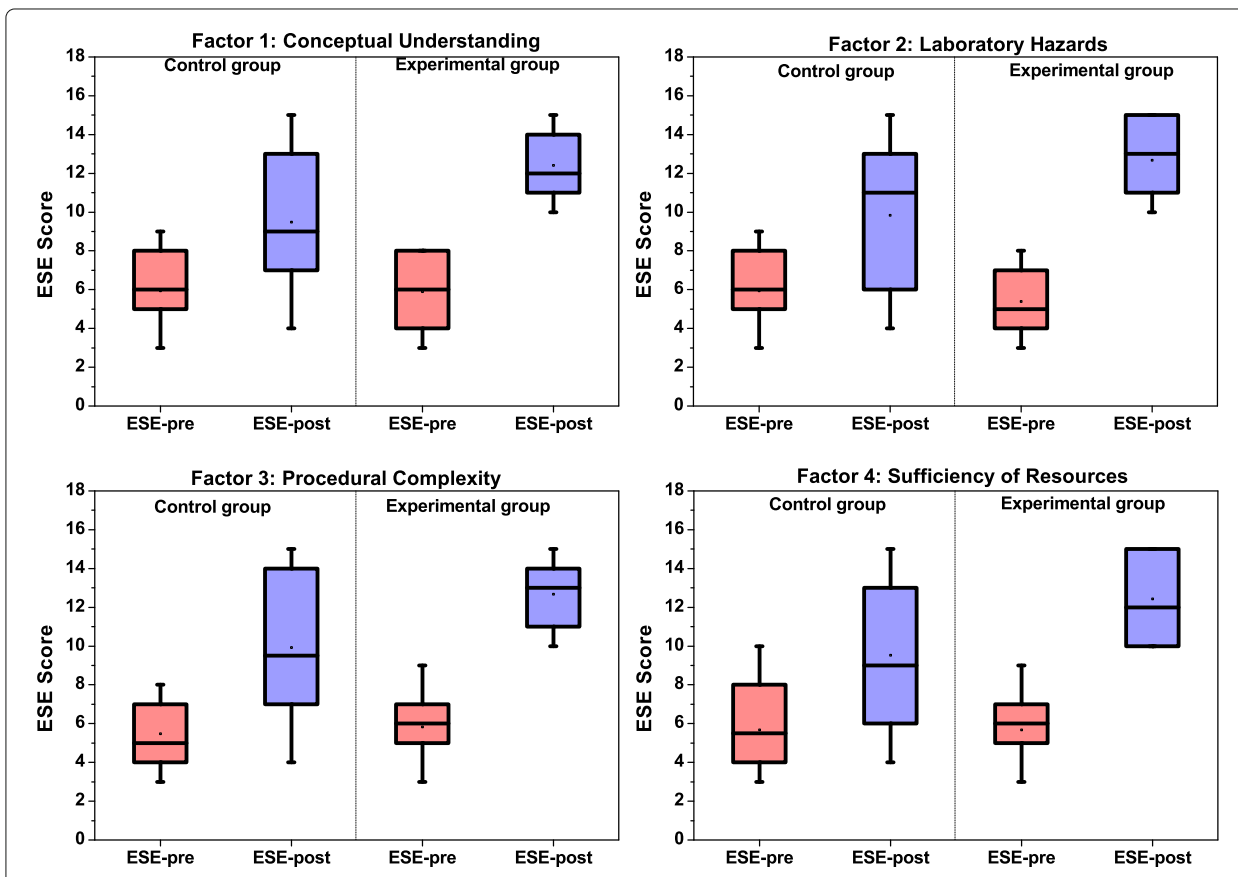

Fig. 6 Box plot shows the score of students of CG and EG in each category of ESE test 
ESE scores between the groups (CG and EG) (Table 6). In the dissimilarity matrix, similar groups show minimum distance (0.000) values and dissimilar groups exhibit higher distance (1.000) value. Compared to CG, EG show maximum Euclidean distance (CU = $1.000, \mathrm{LH}=1.000, \mathrm{PC}=0.943$ and $\mathrm{SR}=1.000$ ) between ESE-pre and ESE-post tests. Based on the dissimilarity matrix and box-plots, we observed that there was a significant improvement in the experimental self-efficacy of students after the introduction of virtual labs in their curriculum. The use of simulations and animations in UG courses have contributed to the improvement of student learning with visual and kinesthetic tools enhancing and reinforcing student understanding in ways that rote learning may not (Ramos et al. 2016). Previous work has indicated the importance of self-efficacy in science education (Makransky et al. 2016a; Thisgaard M and Makransky 2017). Our results indicate that experimental self-efficacy contributes significantly to enhance laboratory education outcomes and using a VL platform aids in the process. Sophisticated simulations are capable of providing a better, holistic picture of a problem compared to a simple drawing. In science, especially chemistry laboratory work, this is highly useful. Further, including VL in the curriculum hones the problem-solving ability of students in performing physical experiments (Avramiotis and Tsaparlis 2013) and sharpens their critical thinking skills (Mashami and Gunawan 2018). Understanding the relevant theory of experiments is an important aspect of problem-solving in laboratories. Traditionally, students are required to digest both theory and procedural information resulting in high cognitive load that affects their laboratory performance. On the other hand, in this study, the VL platform integrates the theory and procedural guidance in an interactive way to

Table 6 Dissimilarity matrix (re-scaled Euclidean distance)

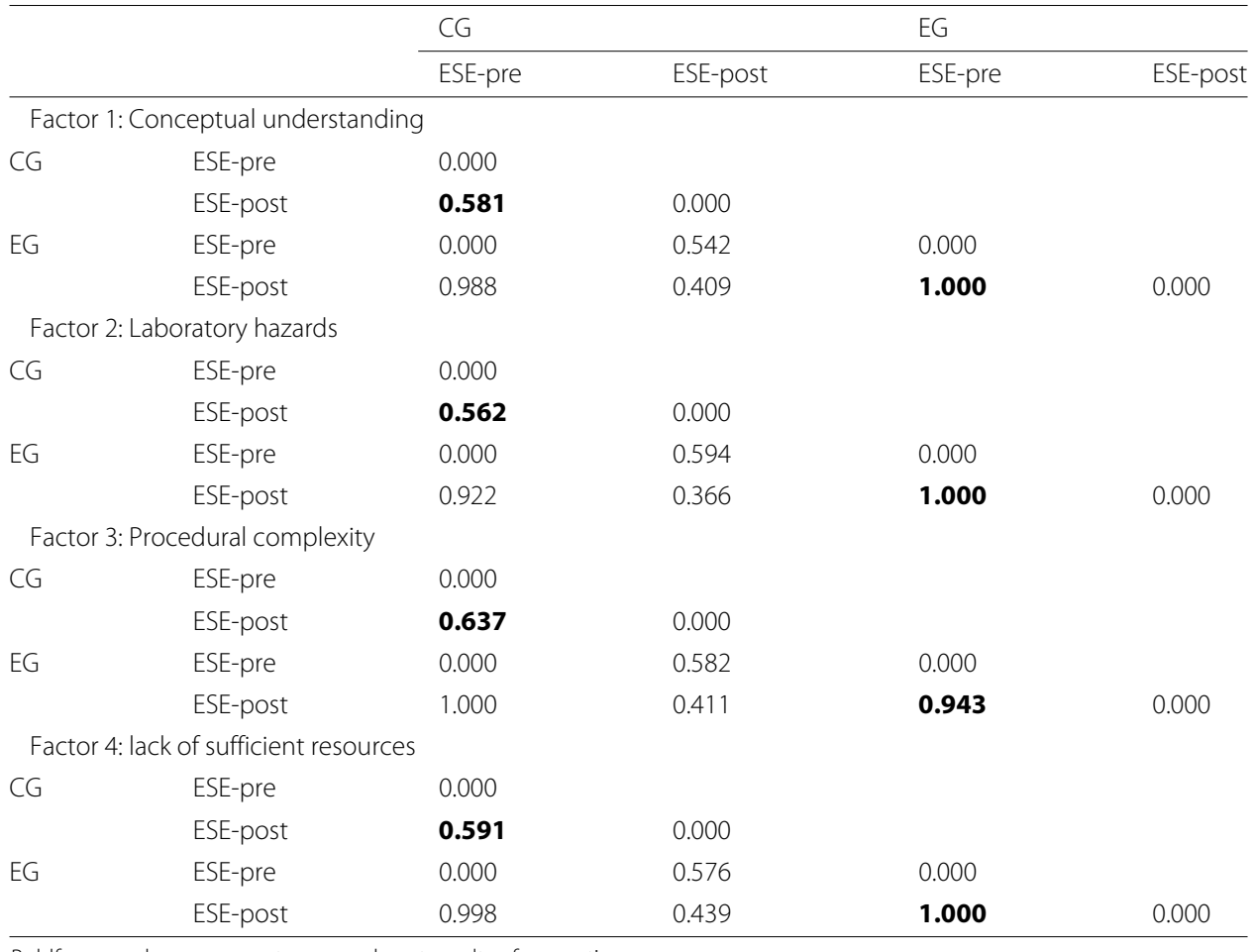

Boldface numbers represents pre- and post results of respective groups 
educate them. This methodology addresses some of the major drawbacks seen in physical laboratories such as lack of materials in laboratories, limited laboratory hours, safety (Redel-Macías et al. 2016; Yang and Heh 2007; Ullah et al. 2016; Rodríguez et al. 2012) and so on quite effectively. Additionally this study offers a systematic characterization of student experimental self-efficacy that manifests from the lack of conceptual understanding $(\mathrm{CU})$, increased procedural complexity (PC), susceptibility to laboratory hazards (LH) and lack of sufficient resources (SR) with regards to performing laboratory experiments. Consequently, results suggest that improving $\mathrm{CU}$ and $\mathrm{PC}$ among students translates to enhanced cognitive performance which may be attributed to the enhanced visualization, the adaptive experimental designs with interactivity and ability to do a wide range of experiments. Concomitantly, addressing LH and SR show marked improvement in physical laboratory performance due to the flexibility in repeating experiments online first prior to doing them in a physical laboratory.

\section{Conclusion}

Laboratory education in STEM disciplines such as chemistry plays a dominant role in the overall professional development of students. However, it is observed that, students experience significantly high anxiety and low self-efficacy in performing laboratory experiments. The outcomes of laboratory education are bound to be compromised when students with low self-efficacy (CG $=50 \%$ and EG $=54 \%$ ) perform laboratory experimentation. This study delves into factors causing low experimental self-efficacy, characterizes it and explores interventions to reduce its impact amongst students performing undergraduate chemistry laboratory. The study considered the two aspects of self-efficacy. Namely, cognitive and physical activity. Using a systematic approach the study identified four dominant factors and they are categorized into to two theoretical aspects of selfefficacy. The four factors are conceptual understanding, laboratory hazards, procedural complexity, and lack of sufficient resources. To increase the experimental self-efficacy, a virtual laboratory learning platform was built that allowed interactivity, wide experimentation and high availability for the shortlisted experiments in this study. A reliable instrument to gauge experimental self-efficacy (ESE) was developed as part of this work. This instrument demonstrated the tangible impact of the virtual experimental learning platform on undergraduate students with low experimental self-efficacy. Using this platform, students were able to deepen their familiarity with and knowledge about both i.e. experiments and instruments. Based on statistical analysis, exposing students to VL and helping them better their understanding through active hands-on learning increases their experimental self-efficacy significantly i.e. a minimum of $88 \%$ to a maximum of $233 \%$. Euclidean distance analysis of pre and post results of control group and experimental group highlights drastic improvements in conceptual understanding, procedural complexity, and alleviating anxiety caused by laboratory hazards and lack of sufficient resources.

\section{Limitations}

Although our findings are encouraging and useful, the authors would like to point out the following major limitations of the study. Firstly, our study focused only on the four identified major factors that impact experimental self-efficacy of students. However, there are other factors like psychological factors or fears stemming from previous mishaps that 
are not considered in this study. The results could also be affected by factors such as cultural differences and teaching experience of instructors that are not taken into consideration. Secondly, studies in other disciplines would help deepen the understanding on experimental self-efficacy.

\section{Supplementary information}

Supplementary information accompanies this paper at https://doi.org/10.1186/s41239-020-00204-3.

Additional file 1: Supplementary information.

\section{Acknowledgements}

This work derives direction and ideas from the Chancellor of Amrita Vishwa Vidyapeetham, Sri Mata Amritanandamayi Devi. Authors would like to thank the VALUE Virtual Labs team and CREATE team at Amrita Vishwa Vidyapeetham in developing and deploying virtual laboratories.

\section{Authors' contributions}

Vysakh Kani Kolil drafted the initial manuscript and conducted the research. Sharanya Muthupalani provided insight and editing of the manuscript. Krishnashree Achuthan provided supervision of the research. All authors read and approved the final manuscript.

\section{Funding}

This work was funded by Virtual Labs project, NMEICT, Ministry of Human Resource Development, Government of India.

\section{Availability of data and materials}

The data that support the findings of this study are available from the corresponding author upon reasonable request.

\section{Competing interests}

The authors declare that they have no competing interests. The data that support the findings of this study are available from the corresponding author upon reasonable request.

Received: 17 January 2020 Accepted: 14 April 2020

Published online: 09 July 2020

\section{References}

Achuthan, K., Sreelatha, K., Surendran, S., Diwakar, S., Nedungadi, P., Humphreys, S., CO, SS., Pillai, Z., Raman, R., Deepthi, A., et al. (2011). The value@ amrita virtual labs project: Using web technology to provide virtual laboratory access to students, In 2011 IEEE Global Humanitarian Technology Conference (pp. 117-121). Seattle: IEEE.

Achuthan, K., Brahmanandan, S., Bose, L.S. (2015). Cognitive load management in multimedia enhanced interactive virtual laboratories, In Advances in Intelligent Informatics (pp. 143-155). Cham: Springer.

Achuthan, K., Francis, S.P., Diwakar, S. (2017). Augmented reflective learning and knowledge retention perceived among students in classrooms involving virtual laboratories. Education and Information Technologies, 22(6), 2825-2855.

Achuthan, K., Kolil, V.K., Diwakar, S. (2018). Using virtual laboratories in chemistry classrooms as interactive tools towards modifying alternate conceptions in molecular symmetry. Education and Information Technologies, 23(6), 2499-2515.

Aikenhead, G.S. (2003). Chemistry and physics instruction: Integration, ideologies, and choices. Chemistry Education Research and Practice, 4(2), 115-130.

Ainsworth, S. (2008). How do animations influence learning, In Current perspectives on cognition, learning, and instruction: Recent innovations in educational technology that facilitate student learning (pp. 37-67). Charlotte: Information Age Publishing.

AIDahdouh, A.A. (2018). Jumping from one resource to another: how do students navigate learning networks? International Journal of Educational Technology in Higher Education, 15(1), 45.

Atkins, P., \& De Paula, J. (2017). Elements of Physical Chemistry. United Kingdom: Oxford University Press. https://books. google.co.in/books?id=bCyhDQAAQBAJ.

Avramiotis, S., \& Tsaparlis, G. (2013). Using computer simulations in chemistry problem solving. Chemistry Education Research and Practice, 14(3), 297-311.

Aydın, YÇ, \& Uzuntiryaki, E. (2009). Development and psychometric evaluation of the high school chemistry self-efficacy scale. Educational and Psychological Measurement, 69(5), 868-880.

BAMU (2020). Syllabus of B.Sc iii year analytical chemistry, Dr Babasaheb Ambedkar Marathwada University, Aurangabad. http://www.bamu.ac.in/Portals/0/B_Sc-III-Year-Syllabus-Sem_-V-\%26-VI-\%5BAnalytical-Chemistry\%5D-2011.pdf. Accessed: 16 Mar.

Bandura, A. (1977). Self-efficacy: toward a unifying theory of behavioral change. Psychological review, 84(2), 191.

Bandura, A. (1981). Self-referent thought: A developmental analysis of self-efficacy. Social cognitive development: Frontiers and possible futures, 200(1), 239.

Bandura, A. (1986). The explanatory and predictive scope of self-efficacy theory. Journal of social and clinical psychology, 4(3), 359-373.

Bandura, A. (1989). Human agency in social cognitive theory. American psychologist, 44(9), 1175.

Bandura, A. (1997). Self-efficacy: The exercise of control. Macmillan. New York: Worth publishers.

Bandura, A., \& Walters, R.H. (1977). Social learning theory. Englewood Cliffs: Prentice-Hall. 
Bautista, N.U., \& Boone, W.J. (2015). Exploring the impact of teachme $e^{\text {mm }}$ lab virtual classroom teaching simulation on early childhood education majors' self-efficacy beliefs. Journal of Science Teacher Education, 26(3), 237-262.

Ben-Eliyahu, A., \& Linnenbrink-Garcia, L. (2013). Extending self-regulated learning to include self-regulated emotion strategies. Motivation and Emotion, 37(3), 558-573.

Betz, N.E., \& Hackett, G. (1983). The relationship of mathematics self-efficacy expectations to the selection of science-based college majors. Journal of Vocational behavior, 23(3), 329-345.

Beydoğan, H., \& Hayran, Z. (2015). The effect of multimedia-based learning on the concept learning levels and attitudes of students. Eurasian Journal of Educational Research, 15, 261 - 279. https://doi.org/10.14689/ejer.2015.60.14.

Boboev, L., Soliev, Z.M., Asrorkulov, F. (2018). The project title: The virtual laboratory and quality of education, In Vocational Teacher Education in Central Asia (pp. 87-91). Cham: Springer.

Bowen, C.W. (1999). Development and score Validation of a chemistry laboratory anxiety instrument (Clai) for College Chemistry Students. Educational and Psychological Measurement, 59(1), 171-185. https://doi.org/10.1177/ 0013164499591012.

Breslow, R. (1993). Let's put an end to 'chemophobia'. Scientist, 7(6), 11.

Bücker, S., Nuraydin, S., Simonsmeier, B.A., Schneider, M., Luhmann, M. (2018). Subjective well-being and academic achievement: A meta-analysis. Journal of Research in Personality, 74, 83-94.

Chemers, M.M., Hu, Lt., Garcia, B.F. (2001). Academic self-efficacy and first year college student performance and adjustment. Journal of Educational psychology, 93(1), 55.

Cobo-Rendón, R., Pérez-Villalobos, M.V., Páez-Rovira, D., Gracia-Leiva, M (2020). A longitudinal study: Affective wellbeing, psychological wellbeing self-efficacy and academic performance among first-year undergraduate students. Scandinavian Journal of Psychology.

Compeau, D.R., \& Higgins, C.A. (1995). Computer self-efficacy: Development of a measure and initial test. MIS Quarterly, 19(2), 189-211. https://doi.org/10.2307/249688.

Cook, A.F. (2013). Cook, Amanda F., (2013) Exploring Freshmen Coll ege Students' Self-Efficacy, Attitudes, and Intentions Toward Chemistry. Honors College Capstone Experience/Thesis Projects. Paper 399. http://digitalcommons.wku.edu/ stu_hon_theses/399.

Cooke, R., Bewick, B.M., Barkham, M., Bradley, M., Audin, K. (2006). Measuring, monitoring and managing the psychological well-being of first year university students. British Journal of Guidance \& Counselling, 34(4), 505-517.

Dalgety, J., \& Coll, R.K. (2006). Exploring first-year science students' chemistry self-efficacy. International journal of science and mathematics education, 4(1), 97-116.

De Jong, T., Linn, M.C., Zacharia, Z.C. (2013). Physical and virtual laboratories in science and engineering education. Science, 340(6130), 305-308.

DeVellis, R. (2016). Scale Development: Theory and Applications Applied Social Research Methods. California: SAGE Publication. https://books.google.co.in/books?id=48ACCwAAQBAJ.

DU (2011). Scheme of examination and courses of reading for B.Sc analytical chemistry, University of Delhi. http://du.ac in/du/uploads/old-ug-courses/1472011_\%20B\%20Sc_Analytical_chem.pdf. Accessed 16 Mar 2020.

Dyrberg, N.R., Treusch, A.H., Wiegand, C. (2017). Virtual laboratories in science education: students' motivation and experiences in two tertiary biology courses. Journal of Biological Education, 51(4), 358-374.

Eakman, A.M., Kinney, A.R., Schierl, M.L., Henry, K.L. (2019). Academic performance in student service members/veterans: Effects of instructor autonomy support, academic self-efficacy and academic problems. Educational Psychology, 39(8), $1005-1026$.

Eddy, R.M. (2000). Chemophobia in the college classroom: Extent, sources, and student characteristics. Journal of Chemical Education, $77(4), 514$.

Feldman, D.B., \& Kubota, M. (2015). Hope, self-efficacy, optimism, and academic achievement: Distinguishing constructs and levels of specificity in predicting college grade-point average. Learning and Individual Differences, 37, 210-216.

Ferrell, B., \& Barbera, J. (2015). Analysis of students' self-efficacy, interest, and effort beliefs in general chemistry. Chemistry Education Research and Practice, 16(2), 318-337.

Fredrickson, B.L. (2013). Positive emotions broaden and build, In Advances in experimental social psychology, vol 47 (pp. 1-53). Amsterdam: Elsevier.

Galyon, C.E., Blondin, C.A., Yaw, J.S., Nalls, M.L., Williams, R.L. (2012). The relationship of academic self-efficacy to class participation and exam performance. Social Psychology of Education, 15(2), 233-249.

Ghergulescu, I., Moldovan, A.N., Muntean, C.H., Muntean, G.M. (2019). Interactive personalised stem virtual lab based on self-directed learning and selfefficacy, In Adjunct Publication of the 27th Conference on User Modeling, Adaptation and Personalization (UMAP'19 Adjunct). (pp. 355-358). Larnaca: ACM Press. https://doi.org/10.1145/3314183.3323678.

Gore Jr, P.A. (2006). Academic self-efficacy as a predictor of college outcomes Two incremental validity studies. Journal of career assessment, 14(1), 92-115.

Goudsouzian, L.K., Riola, P., Ruggles, K., Gupta, P., Mondoux, M.A. (2018). Integrating cell and molecular biology concepts: Comparing learning gains and self-efficacy in corresponding live and virtual undergraduate laboratory experiences. Biochemistry and Molecular Biology Education, 46(4), 361-372.

Heradio, R., de la Torre, L., Galan, D., Cabrerizo, F.J., Herrera-Viedma, E., Dormido, S. (2016). Virtual and remote labs in education: A bibliometric analysis. Computers \& Education, 98, 14-38.

Herga, N.R., Čagran, B., Dinevski, D. (2016). Virtual laboratory in the role of dynamic visualisation for better understanding of chemistry in primary school. Eurasia Journal of Mathematics, Science \& Technology Education, 12(3), 593-608.

Hofstein, A., Nahum, T.L., Shore, R. (2001). Assessment of the learning environment of inquiry-type laboratories in high school chemistry. Learning Environments Research, 4(2), 193-207. https://doi.org/10.1023/A:1012467417645.

Honicke, T., \& Broadbent, J. (2016). The influence of academic self-efficacy on academic performance: A systematic review. Educational Research Review, 17, 63-84.

Hsia, J.W., \& Tseng, A.H. (2008). An enhanced technology acceptance model for e-learning systems in high-tech companies in taiwan: analyzed by structural equation modeling, In Cyberworlds 2008 International Conference on (pp. 39-44). Hangzhou: IEEE. 
Huey, C.C.S. (2013). Assessment of chemistry anxiety among college students, In Chemistry Education and Sustainability in the Global Age (pp. 27-34). Dordrecht: Springer.

Husnaini, S.J., \& Chen, S. (2019). Effects of guided inquiry virtual and physical laboratories on conceptual understanding, inquiry performance, scientific inquiry self-efficacy, and enjoyment. Physical Review Physics Education Research, 15(1), 010119(1)-010119(16).

Jegede, S. (2007). Students anxiety towards the learning of chemistry in some nigerian secondary schools. Educational Research and Reviews, 2(7), 193-197.

Jones, J., \& Young, D.J. (1995). Perceptions of the relevance of mathematics and science: An australian study. Research in Science Education, 25(1), 3-18.

Jones, N. (2018). Simulated labs are booming. Nature, 562(7725), S5-S5.

Judge, T.A., Jackson, C.L., Shaw, J.C., Scott, B.A., Rich, B.L. (2007). Self-efficacy and work-related performance: The integral role of individual differences. Journal of applied psychology, 92(1), 107.

Kamaruddin, N., Ibrahim, N.H., Surif, J. (2015). Attribution factors of chemistry anxiety: What are they? In 2nd International Education Postgrduates Seminars. 20-21 Dec. Johor Bahru, Johor.

Kamaruddin, N.F., Ibrahim, N.H., Johari Surif, M.A., Abd, C. (2019). Malaysian science stream students' anxiety towards chemistry at the secondary school level. International Journal of Recent Technology and Engineering, 7(6S5), 724-738.

Kıran, D., \& Sungur, S. (2012). Middle school students' science self-efficacy and its sources: Examination of gender difference. Journal of Science Education and Technology, 21(5), 619-630.

Korakakis, G., Pavlatou, E.A., Palyvos, J.A., Spyrellis, N. (2009). 3 d visualization types in multimedia applications for science learning: A case study for 8th grade students in greece. Computers \& Education, 52(2), 390-401.

Kırbaşlar, F.G., Veyisoğlu, A., Özsoy Güneş, Z. (2015). Investigating the relationships between pre-service science teachers' self- efficacy in laboratory and anxiety towards chemistry laboratory. Procedia - Social and Behavioral Sciences, 174, 43-50. http://www.sciencedirect.com/science/article/pii/S1877042815006758 International Conference on New Horizons in Education, INTE $201425-27$ June 2014 Paris, France.

Kumar, S., \& Daniel, B.K. (2016). Integration of learning technologies into teaching within fijian polytechnic institutions International Journal of Educational Technology in Higher Education, 13(1), 36.

Kurbanoglu, N.I., \& Akim, A. (2010). The relationships between university students' chemistry laboratory anxiety, attitudes, and self-efficacy beliefs. Australian Journal of Teacher Education, 35(8), 4.

Lasica, I.E., Katzis, K., Meletiou-Mavrotheris, M., Dimopoulos, C. (2016). Research challenges in future laboratory-based stem education. Bulletin of the IEEE Technical Committee on Learning Technology, 18(1), 2.

Lazarowitz, R., \& Tamir, P. (1994). Research on using laboratory instruction in science. In D.L. Gabel (Ed.), Handbook of research on science teaching and learning (pp. 94-130). New York: Macmillan.

Lent, R.W., Brown, S.D., Larkin, K.C. (1984). Relation of self-efficacy expectations to academic achievement and persistence. Journal of counseling psychology, 31(3), 356.

Lorsbach, A., \& Jinks, J. (1999). Self-efficacy theory and learning environment research. Learning environments research, 2(2), 157-167.

Makransky, G., Bonde, M.T., Wulff, J.S., Wandall, J., Hood, M., Creed, P.A., Bache, I., Silahtaroglu, A., Nørremølle, A. (2016a). Simulation based virtual learning environment in medical genetics counseling: an example of bridging the gap between theory and practice in medical education. BMC medical education, 16(1), 98

Makransky, G., Thisgaard, M.W., Gadegaard, H. (2016b). Virtual simulations as preparation for lab exercises: Assessing learning of key laboratory skills in microbiology and improvement of essential non-cognitive skills. PloS ONE, 11(6), e0155,895.

Mashami, R., \& Gunawan, G. (2018). The influence of sub-microscopic media animation on students' critical thinking skills based on gender, In Journal of Physics Conference Series, vol 1108 (p. 012106). Surabaya: IOP Publishing.

Moghadam, A.H., \& Bairamzadeh, S. (2009). Extending the technology acceptance model for e-learning: a case study of Iran, In Information Technology: New Generations 2009 ITNG'09. Sixth International Conference on (pp. 1659-1660). Las Vegas: IEEE.

Nedungadi, P., Ramesh, M.V., Pradeep, P., Raman, R. (2018). Pedagogical support for collaborative development of virtual and remote labs: Amrita vlcap, In Cyber-physical laboratories in engineering and science education (pp. 219-240). Cham: Springer.

Nie, Y., Lau, S., Liau, A.K. (2011). Role of academic self-efficacy in moderating the relation between task importance and test anxiety. Learning and Individual Differences, 21(6), 736-741.

Oriol-Granado, X., Mendoza-Lira, M., Covarrubias-Apablaza, C.G., Molina-López, V.M. (2017). Emociones positivas, apoyo a la autonomía y rendimiento de estudiantes universitarios: el papel mediador del compromiso académico y la autoeficacia. Revista de Psicodidá, ctica, 22(1), 45-53.

Osborne, J.F., \& Collins, S. (2000). Pupils' and parents' views of the school science curriculum. London: London: King's College.

Pagliaro, M. (2010). On shapes, molecules and models: An insight into chemical methodology. European Journal of Chemistry, 1(4), 276-281.

Putwain, D., Sander, P., Larkin, D. (2013). Academic self-efficacy in study-related skills and behaviours: Relations with learning-related emotions and academic success. British Journal of Educational Psychology, 83(4), 633-650.

Raman, R., Nedungadi, P., Achuthan, K., Diwakar, S. (2011). Integrating collaboration and accessibility for deploying virtual labs using vlcap. International Transaction Journal of Engineering, Management, \& Applied Sciences \& Technologies, 2(5), 547-560.

Raman, R., Achuthan, K., Nedungadi, P., Diwakar, S., Bose, R. (2014). The vlab oer experience: Modeling potential-adopter student acceptance. IEEE Transactions on Education, 57(4), 235-241.

Ramnarain, U., \& Ramaila, S. (2018). The relationship between chemistry self-efficacy of south african first year university students and their academic performance. Chemistry Education Research and Practice, 19(1), 60-67.

Ramos, S., Pimentel, E.P., Maria das Graças, B.M., Botelho, W.T. (2016). Hands-on and virtual laboratories to undergraduate chemistry education: Toward a pedagogical integration, In 2016 IEEE Frontiers in Education Conference (FIE) (pp. 1-8). Erie: IEEE. 
Redel-Macías, M., Pinzi, S., Martínez-Jiménez, M., Dorado, G., Dorado, M (2016). Virtual laboratory on biomass for energy generation. Journal of Cleaner Production, 112, 3842-3851.

Reece, A.J., \& Butler, M.B. (2017). Virtually the same: A comparison of stem students content knowledge, course performance, and motivation to learn in virtual and face-to-face introductory biology laboratories. Journal of College Science Teaching, 46(3), 83-89.

Richard, K., Dalgety, J., Salter, D. (2002). The development of the chemistry attitudes and experiences questionnaire (caeq). CHEMISTRY, 3(1), 19-32.

Richardson, M., Abraham, C., Bond, R. (2012). Psychological correlates of university students' academic performance: a systematic review and meta-analysis. Psychological bulletin, 138(2), 353.

Robbins, S.B., Lauver, K., Le, H., Davis, D., Langley, R., Carlstrom, A. (2004). Do psychosocial and study skill factors predict college outcomes? a meta-analysis. Psychological bulletin, 130(2), 261.

Rodríguez, J., Gutiérrez, T., Sánchez, E.J., Casado, S., Aguinaga, I. (2012). Training of Procedural Tasks Through the Use of Virtual Reality and Direct Aids. In C.S. Lanyi (Ed.), Virtual Reality Environments (pp. 43-68). Croatia: InTech.

Schwarzer, R., \& Jerusalem, M. (1995). Generalized self-efficacy scale. In JWeinman SW \& Johnston M (Eds.), Measures in health psychology: A user's portfolio Causal and control beliefs (pp. 35-37). UK: NFER-NELSON: Windsor.

Smist, J.M., \& Owen, S.V. (1994). Explaining science self-efficacy. New Orleans: Paper presented at the annual meeting of the American Educational Research Association.

Stallman, H.M. (2010). Psychological distress in university students: A comparison with general population data. Australian Psychologist, 45(4), 249-257.

Stone, D.C. (2005). Dumber students or dumber teaching? education and the supply of future analytical chemists. Analyst, 130(4), 419-420.

Su, C.H., \& Cheng, T.W. (2019). A sustainability innovation experiential learning model for virtual reality chemistry laboratory: An empirical study with pls-sem and ipma. Sustainability, 11(4), 1027.

Talton, E.L., \& Simpson, R.D. (1986). Relationships of attitudes toward self, family, and school with attitude toward science among adolescents. Science Education, 70(4), 365-74

Tamannaeifar, M.R., \& Motaghedifard, M. (2014). Subjective well-being and its sub-scales among students: The study of role of creativity and self-efficacy. Thinking Skills and Creativity, 12, 37-42.

Tan, Y., \& Arshad, M.Y. (2011). Problem-based learning: Implementation issues in malaysia secondary schools science classroom, In International Conference on Science \& Mathematics Education (CoSMEd). Penang: SEAMEO RECSAM.

Thisgaard M, \& Makransky, G. (2017). Virtual learning simulations in high school Effects on cognitive and non-cognitive outcomes and implications on the development of stem academic and career choice. Frontiers in psychology, 8, 805

Tomás, J.M., Gutiérrez, M., Georgieva, S., Hernández, M. (2020). The effects of self-efficacy, hope, and engagement on the ac ademic achievement of secondary education in the Dominican Republic. Psychology in the Schools, 57(2), 191-203. https://doi.org/10.1002/pits.22321.

Treagust, D., Nieswandt, M., Duit, R. (2000). Sources of students difficulties in learning chemistry. Educació, n química, $11(2), 228-235$.

Trindade, J., Fiolhais, C., Almeida, L. (2002). Science learning in virtual environments: a descriptive study. British Journal of Educational Technology, 33(4), 471-488.

Trojanowicz, M. (2000). Flow Injection Analysis: Instrumentation and Applications. World Scientific, 481. https://books. google.co.in/books?id=I_T6AXfcolwC.

Tymms, P. (1997). Science in primary schools: An investigation into differences in the attainment and attitudes of pupils across schools. Research in Science \& Technological Education, 15(2), 149-159.

UGC (2015). Proposed syllabus and scheme of examination for B.Sc (honors) chemistry. https://www.ugc.ac.in/pdfnews/ 3224345_B.SC.HONOURS-CHEMISTRY.pdf. Accessed 16 Mar 2020.

UGC (2019). Learning outcomes based curriculum framework (LOCF) for (B.SC, with chemistry) undergraduate programme: A template. https://www.ugc.ac.in/pdfnews/6996683_Chemistry.pdf. Accessed 16 Mar 2020.

Ullah, S., Ali, N., Rahman, S.U. (2016). The effect of procedural guidance on students' skill enhancement in a virtual chemistry laboratory. Journal of Chemical Education, 93(12), 2018-2025.

Uzuntiryaki, E., \& Aydın YÇ (2009). Development and validation of chemistry self-efficacy scale for college students. Research in Science Education, 39(4), 539-551.

Uzuntiryaki-Kondakci, E., \& Capa-Aydin, Y. (2013). Predicting critical thinking skills of university students through metacognitive self-regulation skills and chemistry self-efficacy. Educational Sciences: Theory and Practice, 13(1), $666-670$.

Uzuntiryaki-Kondakci, E., \& Senay, A. (2015). Predicting chemistry achievement through task value, goal orientations, and self-efficacy: a structural model. Croatian Journal of Education, 17(3), 725-753.

Villafañe, S.M., Xu, X., Raker, J.R. (2016). Self-efficacy and academic performance in first-semester organic chemistry: testing a model of reciprocal causation. Chemistry Education Research and Practice, 17(4), 973-984.

Vlachopoulos, D., \& Makri, A. (2017). The effect of games and simulations on higher education: a systematic literature review. International Journal of Educational Technology in Higher Education, 14(1), 22.

Waldrop, M.M. (2013). Education online: The virtual lab. Nature News, 499(7458), 268-270.

Wang, K., \& Zhu, C. (2019). Mooc-based flipped learning in higher education students' participation, experience and learning performance. International Journal of Educational Technology in Higher Education, 16(1), 33.

Weng, F., Cheong, F., Cheong, C. (2010). The combined effect of self-efficacy and academic integration on higher education students studying it majors in taiwan. Education and Information Technologies, 15(4), 333-353.

Widener, A. (2018). By the numbers: Who's going to grad school in chemistry and chemical engineering. https://cen.acs. org/articles/96/i9/By-the-numbers-Who-s-going-to-grad-school-in-chemistry-and-chemical-engineering.html. Accessed 21 Apr 2020.

Wilde, N., \& Hsu, A. (2019). The influence of general self-efficacy on the interpretation of vicarious experience information within online learning. International Journal of Educational Technology in Higher Education, 16(1), 1-20.

Williams, J.E. (1994). Gender differences in high school students' efficacy-expectation/performance discrepancies across four subject matter domains. Psychology in the Schools, 31(3), 232-237. 
Winkelmann, K., Baloga, M., Marcinkowski, T., Giannoulis, C., Anquandah, G., Cohen, P. (2014). Improving students' inquiry skills and self-efficacy through research-inspired modules in the general chemistry laboratory. Journal of Chemical Education, 92(2), 247-255.

Wright, A.B., \& Holttum, S. (2012). Gender identity, research self-efficacy and research intention in trainee clinical psychologists in the uk. Clinical Psychology \& Psychotherapy, 19(1), 46-56

Xu, D., Huang, W.W., Wang, H., Heales, J. (2014). Enhancing e-learning effectiveness using an intelligent agent-supported personalized virtual learning environment: An empirical investigation. Information \& Management, 51(4), 430-440.

Yadav, J. (2010). Advanced Practical Physical Chemisty, 29th edn. Krishna Prakashan. Meerut: Krishna Prakashan Media. https://books.google.co.in/books?id=QBzIRrzYeuYC.

Yang, K.Y., \& Heh, J.S. (2007). The impact of internet virtual physics laboratory instruction on the achievement in physics, science process skills and computer attitudes of 10th-grade students. Journal of Science Education and Technology, $16(5), 451-461$

Yu, Y., \& Luo, J. (2018). Dispositional optimism and well-being in college students self-efficacy as a mediator. Social Behavior and Personality: an international journal, 46(5), 783-792.

Yuen, A.H., \& Ma, W.W. (2008). Exploring teacher acceptance of e-learning technology. Asia-Pacific Journal of Teacher Education, 36(3), 229-243.

Yusuf, S.D. (2014). Effects of collaborative learning on chemistry students' academic achievement and anxiety level in balancing chemical equations in secondary school in katsina metropolis, nigeria. Journal of Education and Vocational Research, 5(2), 43-48.

\section{Publisher's Note}

Springer Nature remains neutral with regard to jurisdictional claims in published maps and institutional affiliations.

\section{Submit your manuscript to a SpringerOpen ${ }^{\odot}$ journal and benefit from:}

- Convenient online submission

- Rigorous peer review

- Open access: articles freely available online

- High visibility within the field

- Retaining the copyright to your article

Submit your next manuscript at $\downarrow$ springeropen.com 